\title{
FAKTOR LINGKUNGAN FISIK YANG BERHUBUNGAN DENGAN ANGKA KUMAN UDARA DI RUANG RAWAT INAP KELAS I, II, DAN III RST WIJAYAKUSUMA PURWOKERTO TAHUN 2018
}

\author{
Citra Kusumawardhani U.P ${ }^{1}$ ), Asep Tata Gunawan ${ }^{2}$ ), Tri Cahyono ${ }^{3}$ ) \\ Jurusan Kesehatan Lingkungan, Politeknik Kesehatan Kemenkes Semarang, \\ Jl.Raya baturaden Km.12 Purwokerto, Indonesia
}

\begin{abstract}
Abstrak
Rumah sakit merupakan sarana pelayanan kesehatan yang memungkinkan terjadinya infeksi nosokomial yang bisa disebabkan oleh kuman udara. Data sekunder berupa hasil pemeriksaan bakteriologis menunjukkan bahwa lantai ruang rawat inap srikandi kelas II RST Wijayakusuma Purwokerto tidak memenuhi syarat, yaitu sebesar 26 koloni/ $\mathrm{cm}^{2}$. Besar populasi dalam penelitian ini adalah 67, sedangkan besar sampel adalah 35 sampel. Model analisis yang digunakan adalah Rank Spearman. Pengumpulan data dilakukan dengan pengukuran dan observasi.Rata-rata hasil pengukuran adalah, angka kuman udara $7871,43 \mathrm{CFU} / \mathrm{m}^{3}$, suhu udara $27,35^{\circ} \mathrm{C}$, kelembaban 56,20\%, intensitas pencahayaan 154,63 lux, kepadatan ruang 10,3 $\mathrm{m}^{2} / T T$. Hasil analisis dengan untuk suhu dan angka kuman udara adalah $p=0,465$; rho=0,128, kelembaban dan angka kuman udara adalah $p=0,828$; rho=0,038, intensitas pencahayaan dan angka kuman udara adalah $p=0,061 ;$ rho=0,320, kepadatan ruang dan angka kuman udara adalah $p=0,885$; rho=0,025, ventilasi dan angka kuman udara adalah $p=0,113$; rho=0,273, sarana sirkulasi udara dan angka kuman udara adalah $p=0,636$; rho=0,083. Semua faktor dalam variabel bebas berhubungan tidak signifikan dengan angka kuman udara (nilai p>0,05). Sebaiknya dilakukan desinfeksi rutin setiap bulan sekali untuk menurunkan jumlah angka kuman udara.
\end{abstract}

Kata kunci : angka kuman udara, rumah sakit, kesehatan lingkungan

\begin{abstract}
[Physical Environmental Factor Related With The Number Of Airborne Germs At The I, Ii, And Iii Class Of Inpatient Room Rst Wijayakusuma Purwokerto 2018] Hospital Is An Health Service Tool Which Is Possible Make A Healthcare Associated Infection (Hais) That Can Caused Of The Number Of Airborne Germs. Secondary Data Bacteriology Inspection Result Is point that the floor of $2^{\text {nd }}$ class Srikandi Inpatient room is not full the condition, the result is 26 colony $/ \mathrm{cm}^{2}$. The large of population is 67 , while the large of sample is 35 sample. Analysis model that is used on this research is Rank Spearman. Data collection is done by measurement and observation. Mean of the measurement is, the number of airborne germs is $7871,43 \mathrm{CFU} / \mathrm{m}^{3}$, temperature is $27,35^{\circ} \mathrm{C}$, humidity is $56,20 \%$, lighting intensity is 154,63 lux, room density is $10,3 \mathrm{~m}^{2} / \mathrm{TT}$. Analysis result for temperature and the number of airborne germs is $p=0,465 ;($ rho $)=0,128$, humidity with the number of airborne germs is $p=0,828 ;($ rho $)=0,038$, lighting intensity with the number of airborne germs is $p=0,061$; $($ rho $)=0,320$, density room with the number of airborne germs is $p=0,885 ;($ rho $)=0,025$, ventilation with the number of airborne germs is $p=0,113$; (rho) $=0,273$, means of air circulation with the number of airborne germs is $p=0,636 ;(r h o)=0,083$. All of factors of independent variable is not in significant relation with the number of airborne germs ( $p$ value $>0,05$ ). We recommend that routine desinfection every month to reduce the number of airborne germs.
\end{abstract}

Keywords : The number of airborne germs, hospital, environmental health

1. Pendahuluan

Rumah sakit merupakan sarana pelayanan kesehatan, tempat berkumpulnya orang sakit dan sehat yang memungkinkan terjadinya penularan penyakit,

\footnotetext{
*) citraputri34@gmail.com

**) aseptatagunawan@yahoo.co.id

***) tricahyono37@yahoo.co.id
}

kerusakakan lingkungan dan gangguan kesehatan (Kepmenkes RI No. 1204, 2004).

Infeksi yang didapat di Rumah Sakit disebut infeksi nosokomial. Infeksi nosokomial adalah infeksi yang didapat selama perawatan di rumah sakit yang sebelumnya tidak ada atau diinkubasi pada saat masuk. Infeksi yang terjadi lebih dari 48 jam setelah 
masuk biasanya juga dianggap nosokomial. Infeksi nosokomial terjadi di seluruh belahan dunia dan mempengaruhi negara-negara miskin dan berkembang. Survei prevalensi yang diadakan dibawah naungan WHO pada 55 Rumah Sakit dari 14 negara yang mewakili 4 wilayah WHO (Eropa, Timur Tengah, Asia Tenggara dan Pasifik Barat) menunjukkan rata-rata dari $8,7 \%$ pasien di rumah sakit mendapatkan infeksi nosokomial. Frekuensi tertinggi infeksi nosokomial yang dilaporkan adalah dari rumah sakit - rumah sakit di Timur Tengah dan Asia Tenggara (Masing-masing 11,8 dan 10,0\%), dengan prevalensi berturut-turut 7,7 dan 9,0\% di wilayah Eropa dan Pasifik Barat (WHO, 2002).

Hasil penelitian yang dilakukan oleh Ratna Nugraheni, Suhartono, dan Sri Winarni di RSUD Setjonegoro Kabupaten Wonosobo menunjukkan bahwa angka kejadian infeksi nosokomial di RSUD Setjonegoro Kabupaten Wonosobo adalah pada semester II 2009 prevalensi 2,67 per 1000 pasien rawat inap, semester I 2010 prevalensi 3,12 per 1000 pasien rawat inap, semester II 2010 prevalensi 4,36 per 1000 pasien rawat inap, semester I 2011 prevalensi 9,68 dan semester II 2011 prevalensi 19,71 per 1000 pasien rawat inap.

Abdullah dan Buraerah Abdul Hakim (2011) di RSU Haji Makassar Sulawesi Selatan dengan menggunakan rancangan cross sectional dengan subjek penelitian lima ruang Rawat inap (paviliun, kelas I, kelas II, kelas III, dan recovery room) pada 41 ruang rawat inap menunjukkan bahwa persentase kualitas kualitas fisik udara yang tidak memenuhi syarat sebanding dengan persentase angka kuman yang tidak memenuhi syarat. Semakin tinggi proporsi kualitas lingkungan yang tidak memenuhi syarat, maka akan semakin tinggi pula angka kuman yang tidak memenuhi syarat. Kontribusi terbesar faktor kualitas fisik udara terhadap angka kuman berturutturut adalah kepadatan ruang, kelembapan, pencahayaan, dan suhu ruang. Berdasarkan empat faktor kualitas fisik udara tersebut hanya kelembapan yang memberikan kontribusi secara langsung terhadap angka kuman (nilai $\mathrm{p}=0,023$ ). Pencahayaan, suhu, dan kepadatan ruang tidak mempunyai kontribusi langsung kepada angka kuman ( $>$ > 0,05 untuk ketiga faktor kualitas fisik udara). Ketiga faktor kualitas fisik udara itu saling berkorelasi secara signifikan, yaitu kepadatan ruang dengan suhu (nilai $\mathrm{p}=0,000$ ), kepadatan ruang dengan pencahayaan (nilai $\mathrm{p}=0,001$ ), dan pencahayaan dengan kelembapan (nilai $\mathrm{p}=0,022$ ). Pencahayaan hampir signifikan berkorelasi dengan suhu (nilai $\mathrm{p}=0,053$ ) dan suhu dengan kelembapan (nilai $\mathrm{p}=0,058$ ).
RST Wijayakusuma merupakan rumah sakit yang berada di Kota Purwokerto, beralamat di Jl. Pr.dr.HR.Bunyamin Purwokerto, merupakan rumah sakit peninggalan dari Belanda pada tahun 1949 yang awalnya dahulu berkedudukan di Banyumas dengan nama RST Brigade 8 / III "Sunan Gunung Jati". Tugas Pokok RST Wijayakusuma Purwokerto adalah melaksanakan pembinaan dan pelayanan kesehatan kepada Prajurit TNI, PNS - TNI beserta keluarganya di wilayah Korem 071/Wijayakusuma dalam rangka mendukung tugas pokok Korem 071/Wijayakusuma serta memberikan pelayanan kesehatan kepada masyarakat umum Purwokerto dan sekitarnya. Ruang rawat inap di RST Wijayakusuma Purwokerto terdiri dari lima kelas yaitu kelas Paviliun/ VVIP, VIP, Kelas I, II, dan III. Perbedaan antar kelas tersebut adalah pada fasiitas yang diberikan dan jumlah pasien dalam satu ruangan. Upaya pemantauan yang dilakukan oleh RST Wijayakusuma Purwokerto adalah dengan pengukuran angka kuman secara sampling dan berkala ( 6 bulan sekali) di salah satu ruang rawat inap. Upaya desinfeksi yang dilakukan oleh RST Wijayakusuma adalah desinfeksi terhadap lantai dengan cara mengepel lantai setiap hari. Hasil dari penelitian ini nantinya dapat digunakan sebagai arsip dan dasar pengambilan keputusan terkait dengan angka kuman udara di ruang rawat inap RST Wijayakusuma Purwokerto.

Berdasarkan uraian diatas, maka peneliti tertarik untuk melakukan penelitian berkaitan angka kuman udara dan faktor kualitas lingkungan fisik udara yang mempengaruhinya di ruang rawat inap Srikandi kelas I, II, dan III Rumah Sakit Wijayakusuma Purwokerto dengan judul "Faktor Lingkungan Fisik Yang Berhubungan Dengan Angka Kuman Udara Di Ruang Rawat Inap Kelas I, II, Dan III RST Wijayakusuma Purwokerto Tahun 2018“.

\section{Bahan dan Metode}

Penelitian ini dilakukan dengan observasi secara langsung dan pengukuran angka kuman udara, sehu, kelembapan, intensitas pencahayaan, kepadatan ruang, ventilasi dan sarana sirkulasi udara di ruang rawat inap kelas I, II, dan III. Alat-alat yang digunakan dalam kegiatan observasi dan pengukuran adalah cheklist, thermohygrometer, lucmeter, impinger dan seperangkat media kultur kuman udara. Analisis data menggunakan metode rank spearman.

\section{Hasil dan Pembahasan \\ Angka Kuman Udara Ruang Rawat Inap Kelas I, II, III RST Wijayakusuma Purwokerto}

Jumlah sampel dengan angka kuman udara yang memenuhi syarat di ruang rawat inap kelas I RST Wijayakusuma Purwokerto adalah dua ruangan yaitu ruang Kresna 19A dan Kresna 14B. Nilai angka 
kuman udara yang tertinggi di ruang rawat inap kelas I RST Wijayakusuma Purwokerto adalah 10000 $\mathrm{CFU} / \mathrm{m}^{3}$ yaitu di Ruang Abimanyu 18. Kondisi ruang rawat inap Abimanyu 18 pada saat dilakukan pengambilan sampel adalah jendela tertutup, AC dan lampu menyala dengan jumlah penunggu 1 orang, namun kondisi AC yang berada di ruangan tersebut tidak memenuhi syarat karena berdebu. Nilai angka kuman udara yang terendah di ruang rawat inap kelas I RST Wijayakusuma Purwokerto adalah 500 $\mathrm{CFU} / \mathrm{m}^{3}$ yaitu terletak pada ruang Kresna 19A dan ruang Kresna 14B. Kondisi ruang rawat inap Kresna 19A pada saat dilakukan pengambilan sampel adalah jendela tertutup, AC menyala, lampu mati dan sarana sirkulasi udara memenuhi syarat. Kondisi ruang rawat inap Kresna 14B pada saat dilakukan pengambilan sampel adalah jendela terbuka, AC menyala, sarana sirkulasi udara memenuhi syarat dengan jumlah penunggu 1 orang. Perbedaan antara ruangan yang memenuhi syarat angka kuman udara dengan yang tidak pada ruang rawat inap kelas I RST Wijayakusuma Purwokerto terletak pada kondisi sarana sirkulasi udara (AC).

Jumlah sampel dengan angka kuman udara yang memenuhi syarat di ruang rawat inap kelas II RST Wijayakusuma Purwokerto adalah dua ruangan yaitu ruang Srikandi dan Arimbi. Nilai angka kuman udara yang tertinggi pada ruang rawat inap kelas II RST Wijayakusuma Purwokerto adalah $10500 \mathrm{CFU} / \mathrm{m}^{3}$ yang terletak pada ruang Srikandi (sampel 5). Kondisi ruang rawat inap pada saat dilakukan pengambilan sampel adalah jumlah pasien sebanyak 3 orang dan jumlah penunggu 2 orang, kipas angin menyala 1 , kedua jendela terbuka dan sarana sirkulasi udara memenuhi syarat. Nilai angka kuman udara yang terendah di ruang rawat inap kelas II RST Wijayakusuma Purwokerto adalah $500 \mathrm{CFU} / \mathrm{m}^{3}$ yang terletak pada ruang Srikandi (sampel 6) dan Arimbi (sampel 33). Kondisi ruang Srikandi pada saat dilakukan pengambilan sampel adalah kipas angin menyala 1 , kedua jendela terbuka, jumlah pasien sebanyak 2 orang dengan jumlah penunggu 2 orang dan sarana sirkulasi udara memenuhi syarat. Kondisi ruang Arimbi pada saat dilakuka pengambilan sampel adalah kedua jendela terbuka, 3 kipas angin menyala, jumlah pasien sebanyak 3 orang dengan jumlah penunggu sebanyak 3 orang, sarana sirkulasi udara tidak memenuhi syarat karena kipas angin berdebu. Perbedaan kondisi ruangan antara sampel dengan nilai angka kuman terendah dan tertinggi terletak pada jumlah sarana sirkulasi udara yang digunakan dan jumlah penunggu pasien.

Jumlah sampel dengan angka kuman udara yang memenuhi syarat di ruang rawat inap kelas III RST Wijayakusuma Purwokerto adalah satu ruangan yaitu ruang Parikesit. Nilai angka kuman udara yang tertinggi di ruang rawat inap kelas III RST Wijayakusuma Purwokerto adalah $162250 \mathrm{CFU} / \mathrm{m}^{3}$ yang terletak di ruang Arimbi (sampel 9). Nilai angka kuman ini juga merupakan yang tertinggi dari seluruh ruangan yang menjadi sampel penelitian ini. Kondisi ruangan pada saat dilakukan pengambilan sampel adalah kedua jendela terbuka, kipas angin 1 menyala, jumlah pasien 6 orang dengan jumlah penunggu 6 orang. Pengambilan sampel ruang Arimbi (sampel 9) dilakukan siang hari menjelang jam besuk. Nilai angka kuman udara yang terendah di ruang rawat inap kelas III RST Wijayakusuma Purwokerto adalah ruang Parikesit (sampel 11). Kondisi ruangan pada saat dilakukan pengambilan sampel adalah kedua jendela terbuka, kipas angin 1 menyala, jumlah pasien 3 orang dengan jumlah penunggu 6 orang. Pengambilan sampel ruang Parikesit (sampel 11) dilakukan pada pagi hari ketika belum banyak orang beraktivitas di ruangan tersebut. Perbedaan kondisi ruangan yang memiliki nilai angka kuman udara tertinggi dan terendah di ruang rawat inap kelas III RST Wijayakusuma Purwokerto terletak pada jumlah pasien di dalam ruangan dan waktu pengambilan sampel.

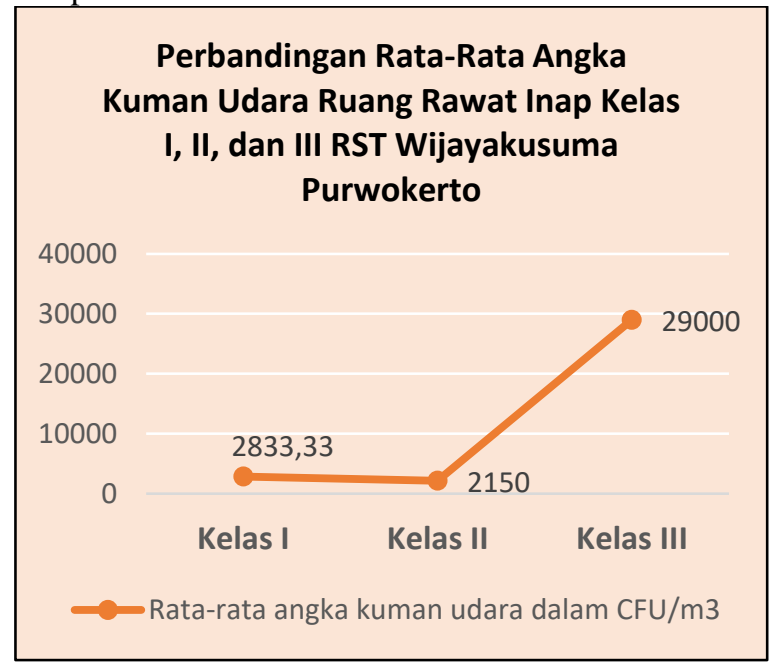

Gambar 4.1 Grafik perbandingan pemenuhan persyaratan angka kuman udara ruang rawat inap kelas I, II, dan III RST Wijayakusuma Purwokerto.

Hasil pemeriksaan angka kuman udara menunjukkan bahwa nilai rata-rata angka kuman udara di Ruang Rawat Inap Kelas I, II, dan III RST Wijayakusuma Purwokerto adalah sebesar $7871,43 \mathrm{CFU} / \mathrm{m}^{3}$, nilai tengah (median) sebesar $1250 \mathrm{CFU} / \mathrm{m}^{3}$, nilai yang paling sering muncul (modus) $500 \mathrm{CFU} / \mathrm{m}^{3}$ yaitu sebanyak 5 kali pada ruangan yang memenuhi syarat. Standar deviasi adalah 27473,14, standar error 4643,81, nilai angka kuman terendah adalah 500 $\mathrm{CFU} / \mathrm{m}^{3}$ dan nilai angka kuman tertinggi adalah $162250 \mathrm{CFU} / \mathrm{m}^{3}$. Banyak sampel yang memenuhi syarat adalah sebanyak 5 sampel yaitu Ruang 
Srikandi Kelas II, Ruang Parikesit Kelas III, Ruang Kresna 19A, Ruang Kresna 14B, dan Ruang Arimbi Kelas II, sedangkan 30 sampel lainnya tidak memenuhi syarat. Terdapat perbedaan yang signifikan antara rata-rata angka kuman udara, nilai yang paling sering muncul, nilai terendah, nilai tertinggi dan standar deviasi. Kelompok ruang yang memberikan kontribusi paling besar yang menyebabkan perbedaan statistik yang mencolok adalah kelompok ruang rawat inap kelas III, yaitu terdapat ruangan dengan angka kuman udara yang jauh diatas rata-rata $\left(32250 \mathrm{CFU} / \mathrm{m}^{3}\right.$ dan 162250 $\mathrm{CFU} / \mathrm{m}^{3}$ pada ruang Arimbi kelas III). Ruangan dengan rata-rata angka kuman udara $32250 \mathrm{CFU} / \mathrm{m}^{3}$ (Ruang Arimbi sampel 8) merupakan ruang rawat inap dengan kondisi tidak terdapat kipas, jendela terbuka, jumlah pasien 5 dengan jumlah penunggu 4 . Ruangan dengan rata-rata angka kuman udara 162250 $\mathrm{CFU} / \mathrm{m}^{3}$ (Ruang Arimbi sampel 9) merupakan ruangan dengan jumlah pasien 6 orang, jumlah penunggu 6 orang, kipas angin 1 menyala, dan jendela terbuka. Persamaan dari kedua ruangan tersebut adalah terdapat pada waktu pengambilan sampel, pengambilan sampel pada ruangan tersebut dilakukan berurutan dengan waktu menjelang jam besuk pasien, sehingga aktivitas di sekitar sudah mulai padat.

Perbedaan angka kuman udara pada masing-masing ruang sebanding dengan perbedaan aktivitas dan jumlah penunggu/ penghuni ruang rawat inap tersebut. Sampel yang memenuhi syarat berasal dari 2 ruang kelas I, 2 ruang kelas II, dan 1 ruang kelas 3 . Aktivitas penghuni di ruang kelas I dan kelas II lebih sedikit dibandingkan dengan aktivitas penghuni di ruang kelas III. Ruang kelas I dan kelas II bersifat lebih private karena jumlah pasien dalam satu ruangan lebih sedikit, sehingga orang yang berlalulalang lebih sedikit dibandingkan dengan yang di ruang rawat inap kelas III. Aktivitas di ruang rawat inap kelas III cenderung lebih banyak karena pasien yang dirawat dalam satu ruang pun lebih banyak, sehingga orang berlalu-lalang akan lebih banyak pula dibandingkan dengan yang di ruang rawat inap kelas I dan II. Hasil penelitian yang dilakukan oleh Merlin (2012) menunjukkan bahwa kelembapan, jumlah orang, dan suhu memiliki hubungan dengan konsentrasi jamur di ruang rawat inap. Konsentrasi jamur pada ruangan dengan kapasitas 1-4 per kamar dan 5-6 per kamar berbeda secara signifikan.

Tata laksana pemeliharaan ruang bangunan di rumah sakit berdasarkan Kepmenkes No. 1204 tahun 2004 adalah, kegiatan pembersihan lantai minimal dilakukan pagi dan sore, pembersihan lantai di ruang perawatan pasien dilakukan setelah pembenahan/ merapikan tempat tidur pasien, jam makan, jam kunjung dokter, kunjungan keluarga dan sewaktu- waktu bilamana diperlukan, pembersihan dilakukan dengan pel dan bahan antiseptik, untuk mengurangi kadar kuman dalam ruang (indoor) 1 (satu) kali sebulan harus didesinfeksi dengan menggunakan aerosol (resorcinol, trietylin glikol) atau disaring dengan electron presipitator atau menggunakan penyinaran ultra violet. Dari kedua hal tersebut, yang sudah dilaksanakan oleh RST Wijayakusuma Purwokerto adalah melakukan pembersihan lantai pagi dan sore menggunakan bahan antiseptik, oleh karena itu sebaiknya dilakukan pula desinfeksi dengan menggunakan aerosol (resorcinol, trietylin glikol) atau disaring dengan electron presipitator atau menggunakan penyinaran ultra violet untuk mengurangi kadar kuman dalam udara.

\section{Suhu Udara di Ruang Rawat Inap Kelas I, II, III RST Wijayakusuma Purwokerto}

Hasil pengukuran suhu yang tertinggi di ruang rawat inap kelas I RST Wijayakusuma Purwokerto adalah $29^{\circ} \mathrm{C}$ yaitu ruang Kresna 14A. Kondisi ruang Kresna 14A pada saat dilakukan pengukuran adalah jendela terbuka, jumlah penunggu 1 orang, di sekitar ruangan tidak terdapat pohon rindang dan AC menyala. Hasil pengukuran suhu yang terendah di ruang rawat inap kelas I RST Wijayakusuma Purwokerto adalah $25,50^{\circ} \mathrm{C}$ yaitu di ruang Srikandi (sampel 2). Kondisi ruangan pada saat dilakukan pengukuran adalah AC menyala, jendela dibuka, tidak ada penunggu pasien, dan di sekitar ruangan terdapat pohon yang rindang. Perbedaan kondisi ruangan dengan suhu udara tertinggi dan terendah adalah terletak pada keberadaan penunggu pasien dan keberadaan pohon di sekitar ruang rawat inap tersebut.

Hasil pengukuran suhu udara yang tertinggi di ruang rawat inap kelas II RST Wijayakusuma Purwokerto adalah $28^{\circ} \mathrm{C}$ yaitu di ruang Antasena (sampel 16). Kondisi ruangan pada saat dilakukan pengukuran adalah jumlah pasien dalam satu ruangan satu orang dengan jumlah penunggu dua orang, menggunakan AC menyala dan jendela yang terbuka. Pengukuran dilakukan pada pukul 10:20 WIB. Hasil pengukuran suhu udara yang terendah di ruang rawat inap kelas II RST Wijayakusuma Purwokerto adalah $26,50^{\circ} \mathrm{C}$ yaitu di ruang Arimbi (sampel 31). Kondisi ruangan pada saat dilakukan pengukuran adalah kipas 1 tidak dinyalakan, jumlah pasien dua orang dengan jumlah penunggu 2 orang, dan jendela terbuka. Pengukuran dilakukan pada pukul 08:45 WIB. Perbedaan kedua ruangan tersebut adalah terletak pada fasilitas sarana sirkulasi udara (kipas, AC, dan jendela) serta waktu pengukuran. Pengukuran yang dilakukan lebih siang menunjukkan suhu udara yang lebih tinggi dibandingkan pagi hari.

Hasil pengukuran suhu udara yang tertinggi di ruang rawat inap kelas III RST Wijayakusuma Purwokerto 
adalah $28^{\circ} \mathrm{C}$ yaitu di ruang Arimbi (sampel 7), ruang Arimbi (sampel 8), dan ruang Antasena (sampel 15). Kondisi ruang Arimbi (sampel 7) pada saat dilakukan pengukuran adalah terdapat 4 orang pasien dengan jumlah penunggu 6 orang, jendela terbuka, dan tidak terdapat kipas angin. Kondisi ruang Arimbi (sampel 8) pada saat dilakukan pengukuran adalah terdapat 5 orang pasien dengan jumlah penunggu 4 orang, jendela terbuka, dan tidak terdapat kipas angin di ruangan tersebut. Kondisi ruang Antasena (sampel 15) pada saat dilakukan pengukuran adalah terdapat 3 orang pasien dengan 3 orang penunggu, jendela terbuka, dan 1 kipas angin menyala. Hasil pengukuran suhu udara yang terendah di ruang rawat inap kelas III RST Wijayakusuma Purwokerto adalah $27,00^{\circ} \mathrm{C}$ yaitu di ruang Parikesit (sampel 11). Kondisi ruangan pada saat dilakukan pengukuran adalah terdapat 3 orang pasien dengan 6 orang penunggu, kopas 1 menyala, dan jendela terbuka. Perbedaan antara ruangan dengan suhu udara yang tertinggi dan terendah adalah terdapat pada fasilitas sarana sirkulasi udara, pada sampel 7 dan 8 tidak terdapat kipas angin, sedangkan pada sampel 11 terdapat kipas angin dan menyala.

\section{Perbandingan Rata-Rata Suhu Udara Ruang Rawat Inap Kelas I, II, dan III RST Wijayakusuma Purwokerto}

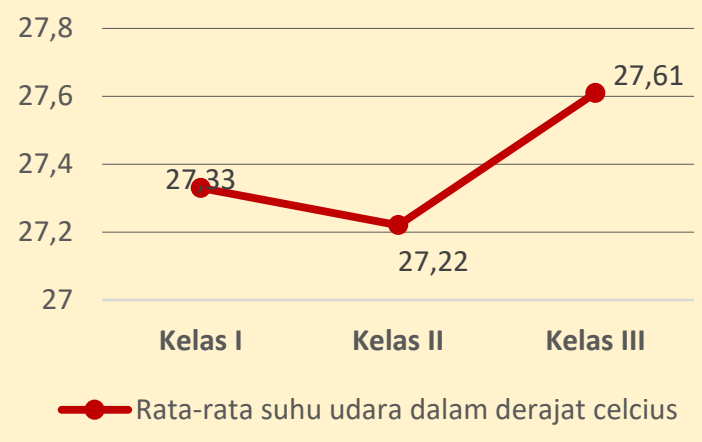

Gambar 4.2 Grafik perbandingan rata-rata suhu udara ruang rawat inap kelas I, II, dan III RST Wijayakusuma Purwokerto.

Pengukuran suhu dilaksanakan selama 15 menit bersamaan dengan pengambilan sampel angka kuman udara. Pengukuran suhu menggunakan alat thermohygrometer. Nilai rata-rata suhu udara di Ruang Rawat Inap Kelas I, II, dan III RST Wijayakusuma Purwokerto adalah sebesar $27,35^{\circ} \mathrm{C}$, nilai tengah (median) sebesar $27,50{ }^{\circ} \mathrm{C}$, nilai yang paling sering muncul (modus) $27,00{ }^{\circ} \mathrm{C}$, standar deviasi adalah 0,72 , standar error 0,12 , hasil pengukuran suhu yang terendah adalah $25,50{ }^{\circ} \mathrm{C}$ dan hasil pengukuran suhu tertinggi adalah $29,00{ }^{\circ} \mathrm{C}$.
Batas maksimal suhu yang dipersyaratkan untuk ruang pemulihan/ perawatan di Kepmenkes No. 1204 Tahun 2004 adalah sebesar $22^{\circ} \mathrm{C}-24^{\circ} \mathrm{C}$. hasil pengukuran di lapangan menunjukkan bahwa seluruh sampel Ruang Rawat Inap Kelas I, II, dan III RST Wijayakusuma Purwokerto tidak memenuhi syarat. Hasil pengukuran suhu sesuai dengan hasil pemeriksaan angka kuman udara yang mayoritas tidak memenuhi syarat, serta sesuai dengan penelitian yang dilakukan oleh Suparmin (2012) yang menunjukkan bahwa mikroba mesophilic yang teridentifikasi di ruang rawat inap RSU Prof. Dr. Margono Soekardjo Purwokerto tumbuh baik pada temperatur $25^{\circ} \mathrm{C}-40^{\circ} \mathrm{C}$. Keadaan di lapangan menunjukkan bahwa ruangan kelas I dan II menggunakan bantuan pendingin ruangan berupa AC, sedangkan untuk ruangan kelas III menggunakan kipas angin. Terdapat 22 ruang yang hanya menggunakan $\mathrm{AC}, 1$ ruang yang menggunakan $\mathrm{AC}$ dan kipas angin yaitu sampel 3 ruang Srikandi kelas II, 10 ruang yang hanya menggunakan kipas angin, dan 2 ruang yang tidak menggunakan AC maupun kipas angin yaitu sampel 7 ruang Arimbi kelas III dan sampel 8 ruang Arimbi kelas III. AC yang digunakan di ruang rawat inap kelas I, II, dan III RST Wijayakusuma Purwokerto merupakan AC split. Kondisi AC secara umum dalam keadaan bisa dipergunakan dan memiliki kartu kontrol.

Hasil penelitian Sugini (2004) menunjukkan bahwa ada beberapa faktor yang mempengaruhi kenyamanan thermal di dalam ruangan yaitu suhu, pergerakan udara/angin, kelembapan, suhu radiasi. Suhu radiasi berasal dari panas matahari, panas matahari yang masuk langsung ke ruangan dapat meningkatkan suhu di dalam ruangan, oleh karena itu sebaiknya apabila tidak terdapat pohon di sekitar ruang yg menghalangi panas matahari untuk langsung masuk ke ruang rawat inap pasien, dipasang gorden untuk mencegah panas matahari masuk secara langsung ke ruangan. Fasilitas-fasilitas penunjang kenyamanan yang berhubungan dengan suhu dan kelembapan seperti AC, kipas angin, dan exhauster yang digunakan sebaiknya dipelihara secara berkala dan digunakan sebagaimana mestinya oleh pasien. Kondisi di lapangan menunjukkan bahwa, meskipun ruang rawat inap telah dilengkapi dengan AC, jendela ruang rawat inap tetap dibuka lebar. Perilaku ini dapat meningkatkan suhu ruangan yang dapat mengganggu kenyamanan pasien. Sebaiknya, apabila sudah menggunakan $\mathrm{AC}$, jendela ruang rawat inap ditutup agar AC dapat berfungsi dengan baik sebagaimana mestinya.Terdapat 2 ruang rawat pada kelas III yang tidak menggunakan AC ataupun kipas angin sama sekali sama sekali yaitu sampel 7 ruang Arimbi kelas III dan sampel 8 ruang Arimbi kelas III, sehingga dimungkinkan dapat mengganggu kenyamanan 
pasien, sebaiknya ditambahkan kipas angin atau AC agar suhu ruangan dapat terkondisikan dengan baik.

\section{Kelembapan Udara di Ruang Rawat Inap Kelas I, II, dan III RST Wijayakusuma Purwokerto}

Terdapat tiga ruang dengan kondisi kelembapan udara tidak memenuhi syarat di ruang rawat inap kelas I RST Wijayakusuma Purwokerto yaitu ruang Srikandi (sampel 2), ruang Abimanyu 15, dan ruang Abimanyu 27. Hasil pengukuran kelembapan yang tertinggi di ruang rawat inap kelas I RST Wijayakusuma Purwokerto adalah 64\% yaitu di ruang Abimanyu 27. Kondisi ruangan pada saat dilakukan pengukuran adalah jumlah pasien satu orang dengan penunggu satu orang, AC tidak dinyalakan, dan lampu tidak dinyalakan. Hasil pengukuran kelembapan yang terendah di ruang rawat inap kelas I RST Wijayakusuma Purwokerto adalah $46 \%$ yaitu di ruang Kresna $18 \mathrm{~B}$ dan ruang Kresna 14A. kondisi ruang Kresna 18B pada saat dilakukan pengukuran adalah jumlah pasien satu orang dengan jumlah penunggu dua orang, jendela terbuka, AC menyala, dan lampu dimatikan. Kondisi ruang Kresna 14A pada saat dilakukan pengukuran adalah jumlah pasien satu orang dengan jumlah penunggu satu orang, jendela terbuka, dan AC menyala. Perbedaan antara kondisi ruangan dengan kelembaban tertinggi dan terendah di ruang rawat inap kelas I RST Wijayakusuma Purwokerto adalah terletak pada kondisi AC dalam keadaan menyala atau tidak.

Terdapat tiga ruang yang tidak memenuhi syarat kelembapan udara di ruang rawat inap kelas II RST Wijayakusuma Purwokerto yaitu ruang Parikesit (sampel 13), ruang Antasena (sampel 16), dan ruang Arimbi (sampel 31). Hasil pengukuran kelembapan yang tertinggi di ruang rawat inap kelas II RST Wijayakusuma Purwokerto adalah 68\% yaitu di ruang Antasena (sampel 16). Kondisi ruangan pada saat dilakukan pengukuran adalah jumlah pasien satu orang dengan jumlah penunggu dua orang, menggunakan AC dan dinyalakan, serta jendela terbuka. Hasil pengukuran kelembaban yang terendah di ruang rawat inap kelas II RST Wijayakusuma Purwokerto adalah $54 \%$ yaitu di ruang Srikandi (sampel 6). Kondisi ruangan pada saat dilakukan pengukuran adalah terdapat dua orang pasien dengan dua orang penunggu, kipas angin menyala, dan jendela terbuka. Perbedaan kondisi kedua ruangan yang memiliki kelembaban tertinggi dan terendah adalah terletak pada sarana sirkulasi udara, yaitu penggunaan $\mathrm{AC}$ dan kipas angin.

Seluruh ruang rawat inap kelas III RST Wijayakusuma Purwokerto memenuhi syarat kelembapan udara. Hasil pengukuran kelembapan yang tertinggi di ruang rawat inap kelas III RST
Wijayakusuma Purwokerto adalah $60 \%$ yaitu di ruang Parikesit (sampel 11). Kondisi ruangan pada saat dilakukan pengukuran adalah terdapat tiga orang pasien dengan jumlah penunggu enam orang, kipas angin menyala, dan jendela terbuka. Hasil pengukuran kelembapan yang terendah di ruang rawat inap kelas III RST Wijayakusuma Purwokerto adalah 53\% yaitu di ruang Arimbi (sampel 8). Kondisi ruangan pada saat dilakukan pengukuran adalah tidak terdapat kipas angin, terdapat lima pasien dengan jumlah penunggu empat orang, dan jendela terbuka. Perbedaan kelembaban udara yang tertinggi dan terendah di ruang rawat inap kelas III RST Wijayakusuma Purwokerto adalah terdapat pada jumlah pasien, jumlah penghuni, dan keberadaan sarana sirkulasi udara (kipas angin).
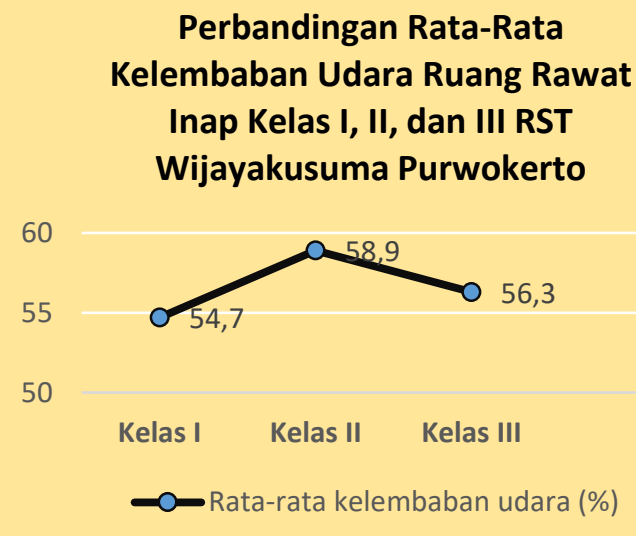

Gambar 4.3 Grafik perbandingan rata-rata kelembapan udara ruang rawat inap kelas I, II, dan III RST Wijayakusuma Purwokerto

Pengukuran kelembapan dilaksanakan selama 15 menit bersamaan dengan pengukuran suhu dan pengambilan sampel angka kuman udara dengan menggunakan thermohygrometer. Nilai rata-rata kelembapan udara di Ruang Rawat Inap Kelas I, II, dan III RST Wijayakusuma Purwokerto adalah sebesar 56,20\%, nilai tengah (median) sebesar 57,00 $\%$, nilai yang paling sering muncul (modus) $54,00 \%$, standar deviasi adalah 5,36, standar error 0,91, hasil pengukuran kelembapan yang terendah adalah 46,00 $\%$ dan hasil pengukuran kelembapan tertinggi adalah $68,00 \%$. Standar kelembapan yang dipersyaratkan untuk ruang pemulihan/ perawatan di Kepmenkes Nomor 1204 tahun 2004 adalah sebesar 45\%-60\%. Banyak nya ruang yang kelembapannya tidak memenuhi syarat adalah 6 ruang yaitu Ruang Srikandi Kelas I, Ruang Parikesit Kelas II, Ruang Antasena Kelas II, Ruang Abimanyu 15 Kelas I, Ruang Abimanyu 27 Kelas I, dan Ruang Arimbi Kelas II, sedangkan 29 ruang lainnya memenuhi syarat. Kelembapan yang tidak memenuhi syarat disebabkan oleh penggunaan AC yang tidak 
maksimal/ sebagaimana mestinya. Penghuni ruang rawat inap di ruangan tersebut diatas menggunakan AC secara bersamaan dengan membuka jendela, sehingga dapat mengurangi efektifitas dari penggunaan AC dan menyebabkan kelembapan tidak memenuhi syarat. Sebaiknya, ketika menggunakan AC penghuni menutup jendela. Apabila tetap tidak memenuhi syarat, maka dapat dipasang humidifier pada ruangan tersebut.

\section{Intensitas Pencahayaan di Ruang Rawat Inap Kelas I, II, dan III RST Wijayakusuma}

Hasil pengukuran intensitas pencahayaan di ruang rawat inap kelas I RST Wijayakusuma Purwokerto menunjukkan bahwa sebanyak lima ruangan tidak memenuhi syarat intensitas pencahayaan yang telah dipersyaratkan di Kepmenkes No. 1204 Tahun 2004 (100-200 lux). Ruangan-ruangan tersebut adalah ruang Abimanyu 27, Abimanyu 24, Kresna 19A, Kresna 19B, Kresna 18A, dan Kresna 14A. Hasil pengukuran intensitas pencahayaan menunjukkan bahwa intensitas pencahayaan yang tertinggi di ruang rawat inap kelas I RST Wijayakusuma Purwokerto adalah 447 lux yaitu di ruang Kresna 19B. Kondisi ruangan tersebut pada saat dilakukan pengukuran adalah lampu dalam keadaan mati dan jendela terbuka lebar. Ruangan dengan intensitas pencahayaan paling rendah di ruang rawat inap kelas I RST Wijayakusuma Purwokerto adalah ruang Abimanyu 9 yaitu 13 lux. Kondisi ruangan pada saat dilakukan pengukuran adalah lampu tidak dinyalakan, ruangan di sekitar merupakan bangunan-bangunan sehingga ruangan gelap. Perbedaan antara kondisi ruangan dengan intensitas pencahayaan tertinggi dan terendah adalah terdapat pada lokasi ruangan dan bangunan di sekitar ruangan. Pada ruang Kresna bangunan berapa di sekitar lahan terbuka dengan jarak antara blok bangunan lebih jauh, sedangkan pada ruang Antasena jarak antar bangunan kebih dekat sehingga menghalangi cahaya masuk ke ruangan.

Terdapat delapan ruang rawat inap kelas II RST yang memiliki intensitas pencahayaan tidak memenuhi syarat, sedangkan dua ruang lainnya memenuhi syarat yaitu ruang Srikandi (sampel 5) dan ruang Arimbi (sampel 10) antara 100-200 lux (Kepmenkes No. 1204 Tahun 2004). Hasil pengukuran menunjukkan bahwa ruang rawat inap kelas II dengan internsitas pencahayaan tertinggi adalah ruang Parikesit (sampel 13) yaitu 381 lux. Kondisi ruangan pada saat dilakukan pengukuran adalah jendela dalam keadaan terbuka sehingga cahaya matari masuk. Hasil pengukuran dengan intesitas pencahayaan yang terendah di ruang rawat inap kelas II adalah ruang Arimbi (sampel 32) yaitu 52 lux. Kondisi ruangan pada saat dilakukan pengukuran jendela dalam keadaan terbuka.
Terdapat dua ruangan yang memenuhi syarat intensitas pencahayaan di ruang rawat inap kelas III RST Wijayakusuma Purwokerto yaitu ruang Arimbi, sedangkan 5 ruangan lainnya tidak memenuhi persyaratan. Hasil pengukuran intensitas pencahayan yang tertinggi di ruang rawat inap kelas III RST Wijayakusuma Purwokerto adalah ruang Parikesit (sampel 11) yaitu 892 lux. Kondisi ruangan dan sekitarnya pada saat dilakukan pengukuran adalah jendela terbuka dan tidak ada pohon rindang di sekitar ruangan. Hasil pengukuran intensitas pencahayaan yang terendah di ruang rawat inap kelas III RST Wijayakusuma Purwokerto adalah 24 lux yaitu di ruang Antasena (sampel 14). Kondiisi ruangan dan sekitarnya pada saat dilakukan pengukuran adalah jendela dalam keadaan tertutup, sehingga tidak banyak cahaya dari luar yang masuk. Perbedaan dari kedua ruang dengan intensitas pencahayaan tertinggi dan terendah di ruang rawat inap kelas III RST Wijayakusuma Purwokerto terletak pada kondisi jendela yang terbuka dan tertutup.

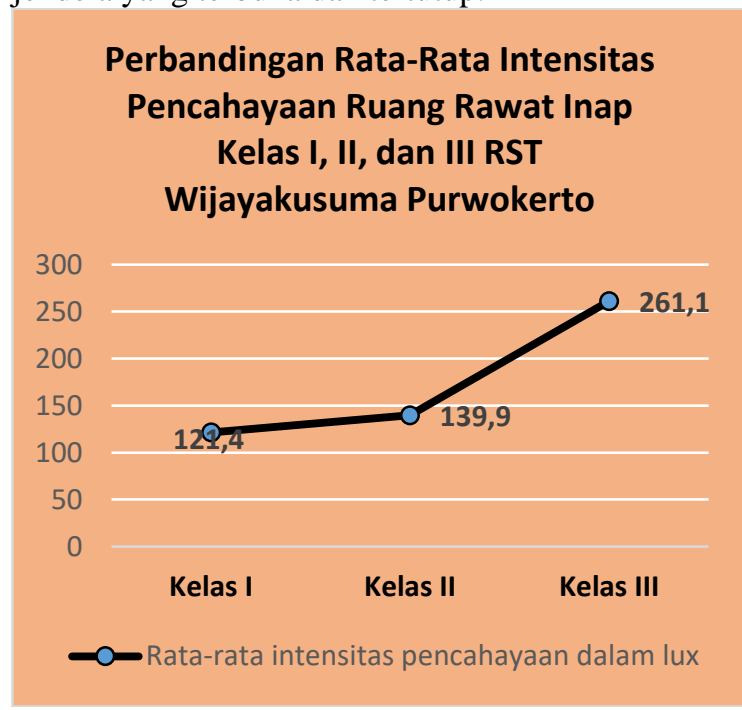

Gambar 4.4 Grafik perbandingan rata-rata intensitas pencahayaan ruang rawat inap kelas I, II, dan III RST Wijayakusuma Purwokerto

Pengukuran intensitas pencahayaan menggunakan lightmeter/ luxmeter. Sumber cahaya di ruang rawat inap kelas I, II, dan III RST Wijayakusuma Purwokerto pada saat dilakukan pengukuran adalah sumber cahaya alami dan buatan (lampu). Tidak ada perlakuan khusus pada sumber cahaya pada saat pengukuran, semua dibiarkan sesuai dengan kebiasaan pasien. Nilai rata-rata intensitas pencahayaan di Ruang Rawat Inap Kelas I, II, dan III RST Wijayakusuma Purwokerto adalah sebesar 154,63 Lux, nilai tengah (median) sebesar 128,00 Lux, nilai yang paling sering muncul (modus) 24,00 Lux, standar deviasi adalah 166.94, standar error 28,22 , hasil pengukuran intensitas pencahayaan yang 
terendah adalah 13,00 Lux dan hasil pengukuran intensitas pencahayaan yang tertinggi adalah 892,00 Lux.

Pengukuran dilaksanakan pada waktu siang hari, sehingga diasumsikan bahwa waktu-waktu tersebut merupakan waktu ketika pasien tidak sedang tidur. Standar intensitas cahaya ruang pasien pada saat tidak tidur berdasarkan Kepmenkes RI Nomor 1204 Tahun 2004 adalah sebesar 100-200 lux. Jumlah ruangan dengan intensitas pencahayaan yang memenuhi syarat adalah sebanyak 10 ruang atau 28,60\%, sedangkan jumlah ruang dengan intensitas pencahayaan yang tidak memenuhi syarat adalah sebanyak 25 ruang atau $71,40 \%$. Keadaan tidak memenuhi syarat ini sebanyak 16 ruang tidak memenuhi syarat karena kurang dari standar yang telah dipersyaratkan, sedangkan 9 ruang tidak memenuhi syarat karena lebih dari standar yang telah dipersyaratkan. Persentase ruang yang tidak memenuhi syarat karena kekurangan cahaya lebih besar dibandingkan dengan persentase yang tidak memenuhi syarat karena kelebihan cahaya.

Hasil penelitian ini, banyaknya ruang dengan intensitas cahaya yang tidak memenuhi syarat karena melebihi standar lebih sedikit daripada banyaknya ruang yang tidak memenuhi syarat karena intensitas cahaya kurang dari standar. Teori ini sesuai dengan hasil penelitian yang mana ruangan dengan angka kuman udara tidak memenuhi syarat lebih banyak dari pada yang memenuhi syarat, dan intensitas cahaya yang kurang dari standar lebih banyak daripada intensitas yang lebih dari standar. Kondisi ruangan yang intensitas cahayanya kurang dari batas minimal yang dipersyaratkan adalah ruang yang ketika dilakukan pengukuran keadaan ruangan yang biasa dihuni oleh pasien tersebut tertutup. Jendela dan pintu tidak dibuka, gorden tidak sepenuhnya dibuka, dan lokasi tempat tidur pasien tidak berdekatan dengan sumber cahaya alami (jendela), selain itu lokasi ruang rawat inap yang berdekatan dengan pepohonan juga membuat ruangan menjadi lebih gelap.

Sebaiknya, apabila pasien tidak terbiasa dengan keadaan jendela atau gorden yang terbuka, maka lampu dinyalakan agar kondisi ruangan menjadi lebih terang terutama ketika jam kunjung dan pelayanan. Kebiasaan membuka jendela dan gorden ini dapat dimulai oleh petugas yang melakukan visitasi ke ruangan setiap hari agar dapat diikuti oleh pasien kemudian. Penataan lokasi tempat tidur pasien, sebaiknya disesuaikan dengan sumber cahaya alami agar pasien mendapatkan cahaya secara alami pada siang hari.
Kepadatan Ruang Rawat Inap Kelas I, II, dan III RST Wijayakusuma Purwokerto

Seluruh ruang rawat inap kelas I dan kelas II RST Wijayakusuma Purwokerto sudah memenuhi standar kepadatan ruang sesuai Kepmenkes Nomor 1204 Tahun $2004\left(4,5 \mathrm{~m}^{2} / \mathrm{TT}\right)$. Jumlah pasien dalam satu ruang untuk kelas I adalah satu orang pasien per ruang, sedangkan untuk kelas II adalah 2-3 pasien per kamar. Ruang yang paling luas di ruang rawat inap kelas I RST Wijayakusuma Purwokerto adalah ruang Abimanyu 24 yaitu $18,75 \mathrm{~m}^{2} / \mathrm{TT}$, sedangkan ruang yang paling sempit di ruang rawat inap kelas I adalah ruang Srikandi yaitu $8,80 \mathrm{~m}^{2} / \mathrm{TT}$. Ruang yang paling luas di ruang rawat inap kelas II RST Wijayakusuma Purwokerto adalah Srikandi (sampel 6) dan Parikesit (sampel 13) yaitu $12,38 \mathrm{~m}^{2} / \mathrm{TT}$, sedangkan ruang yang paling sempit di ruang rawat inap kelas II adalah ruang Srikandi (sampel 3) dan Arimbi (sampel 31) yaitu $7,79 \mathrm{~m}^{2} / \mathrm{TT}$.

Jumlah pasien dalam ruang rawat inap kelas III adalah enam pasien dalam satu ruangan. Terdapat empat ruangan yang memenuhi syarat kepadatan ruang yaitu ruang Srikandi (sampel 4), ruang Arimbi (sampel 8), ruang Antasena (sampel 14 dan 15) dengan kepadatan ruang lebih dari $4,5 \mathrm{~m}^{2} / \mathrm{TT}$. Tiga ruang yang lainnya tidak memenuhi syarat $(<4,5$ $\mathrm{m}^{2} / \mathrm{TT}$ ) yaitu ruang Arimbi (sampel 7), ruang Arimbi (sampel 9), dan ruang Parikesit (sampel 11). Ruang rawat inap kelas III yang paling luas adalah ruang Antasena yaitu $6,41 \mathrm{~m}^{2} / \mathrm{TT}$, sedangkan yang paling sempit adalah ruang Arimbi (sampel 7) yaitu 3,90 $\mathrm{m}^{2} / \mathrm{TT}$.

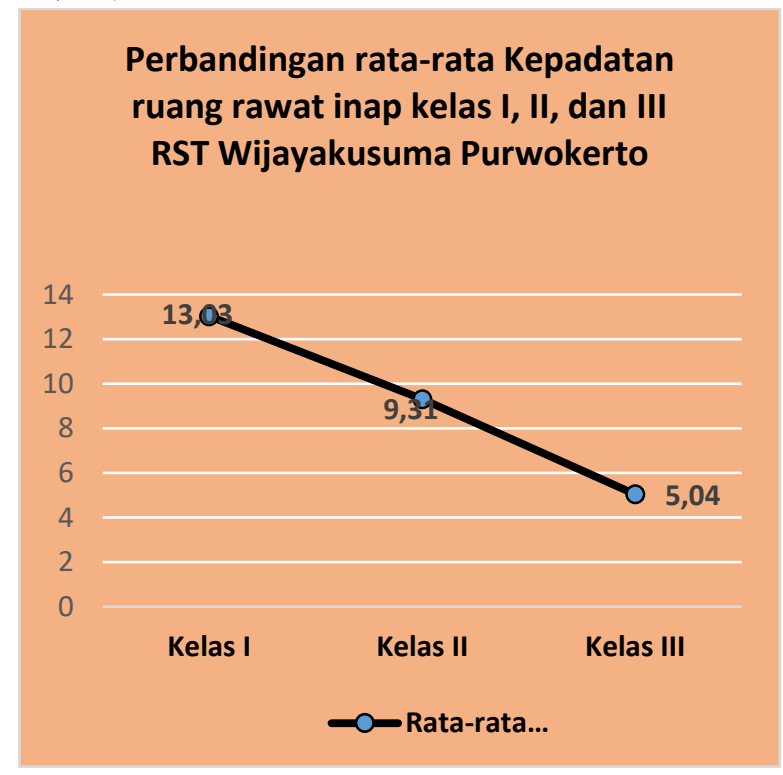

Gambar 4.5 Grafik perbandingan rata-rata kepadatan ruang rawat inap kelas I, II, dan III RST Wijayakusuma Purwokerto 
Standar kepadatan ruang perawatan berdasarkan Kepmenkes Nomor 1204 Tahun 2004 adalah 4,5 $\mathrm{m}^{2} / \mathrm{TT}$ untuk dewasa. Kepadatan ruang dalam penelitian ini adalah perbandingan antara luas lantai per tempat tidur. Nilai rata-rata kepadatan ruang di ruang rawat inap kelas I, II, dan III RST Wijayakusuma Purwokerto adalah sebesar 10,33 $\mathrm{m}^{2} /$ TT, nilai tengah (median) sebesar $9,75 \mathrm{~m}^{2} / \mathrm{TT}$, nilai yang paling sering muncul (modus) $12,38 \mathrm{~m}^{2} / \mathrm{TT}$, standar deviasi adalah 3,84, standar error 0,65 , hasil pengukuran kepadatan ruang yang terendah adalah 3,90 $\mathrm{m}^{2} / \mathrm{TT}$ dan hasil pengukuran kepadatan ruang yang tertinggi adalah $18,75 \mathrm{~m}^{2} / \mathrm{TT}$.

Jumlah ruangan dengan kepadatan ruang yang memenuhi syarat adalah sebanyak 32 ruang atau 91,40 \%, sedangkan jumlah ruang dengan kepadatan ruang yang tidak memenuhi syarat adalah sebanyak 3 ruang atau 8,60\%. Kepadatan ruang yang dimaksud oleh peneliti adalah perbandingan antara luas lantai dengan jumlah tempat tidur pasien. Ruang yang memiliki kepadatan kurang dari standar yang dipersyaratkan disebabkan oleh jumlah pasien di dalam ruang yang terlalu banyak. Ruangan yang tidak memenuhi syarat berasal dari ruang rawat inap kelas III yaitu ruang Arimbi dan Parikesit, yang mana dalam satu ruangan terdiri dari 6 tempat tidur. Apabila dirasa ruangan kurang cukup, sebaiknya ruang rawat inap kelas III bisa ditukar dengan ruangruang lain yang memiliki perbandingan luas lantai dengan jumlah tempat tidur yang lebih luas dibandingkan dengan kedua ruang tersebut, apabila tidak memungkinkan maka sebaiknya dibatasi jumlah penunggu dalam ruang rawat inap tersebut.

\section{Ventilasi di Ruang Rawat Inap Kelas I, II, dan III RST Wijayakusuma Purwokerto}

Ventilasi yang digunakan di RST Wijayakusuma Purwokerto untuk ruang kelas II dan III adalah ventilasi permanen berupa lubang angin dan jendela yang sekaligus digunakan sebagai ventilasi. Sedangkan pada ruang kelas I menggunakan AC split untuk masing-masing ruangannya. Persyaratan ventilasi berdasarkan Kepmenkes Nomor 1204 Tahun 2004 untuk yang menggunakan ventilasi alami minimal $15 \%$ dari luas lantai, sedangkan untuk yang untuk yang menggunakan ventilasi mekanis minimal harus ada fan atau AC. Dari total sebanyak 35 ruang di Ruang Rawat Inap Kelas I, II, dan III RST Wijayakusuma Purwokerto yang diukur, jumlah ruangan dengan ventilasi yang memenuhi syarat adalah sebanyak 34 ruang atau 97,10 \%, sedangkan jumlah ruang dengan ventilasi yang tidak memenuhi syarat adalah sebanyak 1 ruang atau 2,90\%. Ruang kelas I Abimanyu menggunakan ventilasi mekanis berupa AC dan tidak menggunakan lubang ventilasi alami berupa jendela, sedangkan ruang kelas I Kresna menggunakan AC dan ventilasi mekanis berupa jendela yang dapat dibuka. Ruang kelas II ada yang menggunakan AC, kipas angin, dan atau keduanya. Ruang kelas III menggunakan kipas angin dan jendela yang dapat dibuka. Menurut NIOSH dalam jurnal penelitian Evi Wulandari (2013), penyebab timbulnya masalah kualitas udara dalam ruangan sebanyak $52 \%$ disebabkan oleh kurangnya ventilasi udara. Dan $48 \%$ oleh beberapa faktor lain. Dalam penelitian ini, angka kuman udara dalam ruangan dibebakan oleh $48 \%$ faktor lain yang dikemukakan oleh NIOSH yaitu berupa kontaminasi, bahan material, dll.

\section{Sarana Sirkulasi Udara di Ruang Rawat Inap Kelas I, II, dan III RST Wijayakusuma}

Jumlah ruangan dengan sirkulasi udara yang memenuhi syarat adalah sebanyak 29 ruang atau $82,90 \%$, sedangkan jumlah ruang dengan sirkulasi udara yang tidak memenuhi syarat adalah sebanyak 6 ruang atau $17,10 \%$. Penilaian memenuhi syarat atau tidak memenuhi syarat mengacu pada Kepmenkes No. 1204 tahun 2004 tentang Persyaratan Kesehatan Lingkungan di Rumah Sakit. Penyebab tidak memenuhi syarat sirkulasi Udara dalam penelitian ini adalah adanya debu/ kotoran pada fan, exhaust atau AC yang digunakan di dalam ruang rawat inap kelas I, II, dan III RST Wijayakusuma Purwokerto.

Hasil penelitian Evi Wulandari (2013), menunjukkan bahwa sanitasi atau yang biasa disebut kebersihan ruangan yang baik dan terjaga dapat mengurangi risiko adanya mikroba di udara. Menurut Irianto (2006) dalam penelitian Evi, sanitasi ruangan yang buruk akan menyebabkan ruangan kotor dan berdebu, debu yang menempel dapat membuat udara di dalam ruangan menjadi lebih lembab. Udara lembab menyebabkan naiknya suhu di dalam ruangan, kondisi ruangan yang lembab dan bersuhu tinggi yang menyebabkan mikroba dapat berkembang biak.

\section{Analisis Bivariat}

Tabel 4.32 Rekapitulasi Analisis Bivariat

\begin{tabular}{|c|c|c|c|c|}
\hline No & Variabel & $\begin{array}{c}\text { Nilai } \\
\text { R }\end{array}$ & $\begin{array}{l}\text { Nilai } \\
\text { p }\end{array}$ & Ket \\
\hline \multirow[t]{2}{*}{1} & Suhu & 0,12 & 0,46 & Tidak \\
\hline & $\begin{array}{l}\text { Angka Kuman } \\
\text { Udara }\end{array}$ & 8 & 5 & Signifikan \\
\hline \multirow[t]{2}{*}{2} & Kelembapan & 0,03 & 0,82 & Tidak \\
\hline & $\begin{array}{l}\text { VS Angka } \\
\text { Kuman Udara }\end{array}$ & 8 & 8 & Signifikan \\
\hline \multirow[t]{2}{*}{3} & Intensitas & 0,32 & 0,06 & Tidak \\
\hline & $\begin{array}{l}\text { Pencahayaan } \\
\text { VS Angka } \\
\text { Kuman Udara }\end{array}$ & 0 & 1 & Signifikan \\
\hline \multirow[t]{2}{*}{4} & Kepadatan & 0,02 & 0,88 & Tidak \\
\hline & Ruang VS & 5 & 5 & Signifikan \\
\hline
\end{tabular}




\begin{tabular}{rlrrl}
\hline No & Variabel & $\begin{array}{c}\text { Nilai } \\
\text { R }\end{array}$ & $\begin{array}{c}\text { Nilai } \\
\text { p }\end{array}$ & Ket \\
\hline \multirow{4}{*}{5} & Angka Kuman & & & \\
Udara & & & \\
& Ventilasi VS & 0,27 & 0,11 & Tidak \\
& Angka Kuman & 3 & 3 & Signifikan \\
& Udara & & & \\
6 & Sarana & 0,08 & 0,63 & Tidak \\
& Sirkulasi & 3 & 6 & Signifikan \\
& Udara VS & & & \\
Angka Kuman & & & \\
Udara & & & \\
\hline
\end{tabular}

Analisis Bivariat menggunakan metode Rank Spearman pada aplikasi pengolah data statistik. Hasil analisis menunjukkan bahwa, variabel yang memiliki koefisien korelasi tertinggi dengan angka kuman udara adalah intensitas pencahayaan yaitu sebesar 0,320 dan masuk dalam katagori tingkat hubungan rendah. Nilai signifikansi atau nilai p dari intensitas pencahayaan adalah $\mathrm{p}=0,061$. Variabel yang memiliki koefisien korelasi terendah dengan angka kuman udara adalah kepadatan ruang yaitu 0,025 dan masuk dalam katagori tingkat hubungan sangat rendah. Nilai signifikansi atau nilai $\mathrm{p}$ dari kepadatan ruang adalah $\mathrm{p}=0,885$.

\section{Hubungan Suhu dengan Angka Kuman Udara di Ruang Rawat Inap Kelas I, II, dan III RST Wijayakusuma Purwokerto}

Hasil analisis menunjukkan bahwa nilai $\mathrm{p}=0,465$. Nilai $\mathrm{p}=0,465>0,05$ yang berarti tidak terdapat hubungan yang bermakna antara suhu dengan angka kuman udara. Nilai koefisien korelasi rho antara suhu dengan angka kuman udara adalah sebesar 0,128. Tingkat hubungan suhu dengan angka kuman udara berdasarkan katagorisasi koefisien korelasi rho menurut Sugiyono (2007, h.31), termasuk dalam katagori sangat rendah. Hasil penelitian ini tidak sesuai dengan penelitian yang dilakukan oleh Evi Wulandari (2013) dimana hasil penelitiannya menyebutkan bahwa terdapat hubungan yang bermakna antara suhu dengan bakteri Streptococcus di ruangan. Perbedaan penelitian ini dengan penelitian yang dilakukan oleh Evi Wulandari adalah terletak pada lokasi, jumlah sampel, dan analisis data yang dilakukan. Lokasi dari penelitian Evi Wulandari terletak di Rumah Susun dengan jumlah sampel 32 sampel dan uji chi square, sedangkan pada penelitian ini dilakukan di rumah sakit dengan jumlah sampel 35 sampel dan uji Rank Spearman. Penyebaran angka kuman udara dapat berasal dari aktivitas penghuni, petugas rumah sakit, dan penderita yang dapat saling memindahkan kuman.
Hubungan Kelembapan dengan Angka Kuman Udara di Ruang Rawat Inap Kelas I, II, dan III RST Wijayakusuma Purwokerto

Nilai $\mathrm{p}=0,828$. Nilai $\mathrm{p}=0,828>0,05$ dari hasil analisis hubungan kelembapan dengan angka kuman udara dengan metode Rank Spearman dengan aplikasi SPS. Hal ini berarti terdapat hubungan yang tidak bermakna antara kelembapan dengan angka kuman udara. Nilai koefisien korelasi rho antara kelembapan dengan angka kuman udara adalah sebesar 0,038. Tingkat hubungan kelembapan dengan angka kuman udara berdasarkan katagorisasi koefisien korelasi rho menurut Sugiyono (2007, h.31), termasuk dalam katagori sangat rendah.

Hasil penelitian ini tidak sesuai dengan penelitian yang dilakukan oleh M. Tahir Abdullah dan Buraerah Abdul Hakim yang menunjukkan bahwa kelembapan secara langsung berhubungan dengan angka kuman udara (nilai $\mathrm{p}=0,023$ ). Perbedaan penelitian ini dengan penelitian M. Tahir Abdullah dan Buraerah Abdul Hakim (2011) adalah terletak pada lokasi, sampel dan jumlah dan titik pengukuran. Penelitian ini menggunakan sampel ruang rawat inap kelas I, II, dan III serta menetapkan satu titik dan satu kali pengukuran pada setiap ruang yang menjadi anggota sampel. Penelitian M. Tahir Abdullah dan Buraerah Abdul Hakim (2011) menggunakan sampel 5 ruang rawat inap yaitu ruang paviliun, kelas I, kelas II, kelas III dan recovery room, pengukuran dilakukan $3 \mathrm{x}$ (pagi, siang, dan sebelum matahari terbenam) pada 3 titik pengukuran berbeda setiap ruangan.

Hubungan Intensitas Pencahayaan dengan Angka Kuman Udara di Ruang Rawat Inap Kelas I, II, dan III RST Wijayakusuma Purwokerto

Nilai p dari hubungan intensitas pencahayaan dengan angka kuman udara berdasarkan analisis dengan menggunakan metode Rank Spearman dengan aplikasi pengolah data statistik menunjukkan bahwa nilai $\mathrm{p}=0,061>0,05$ yang berarti terdapat hubungan yang tidak bermakna antara intensitas pencahayaan dengan angka kuman udara. Nilai koefisien korelasi rho antara intensitas pencahayaan dengan angka kuman udara adalah sebesar 0,320. Tingkat hubungan intensitas pencahayaan dengan angka kuman udara berdasarkan katagorisasi koefisien korelasi rho menurut Sugiyono (2007, h.31), termasuk dalam katagori rendah.

Variabel intensitas pencahayaan memiliki koefisien korelasi yang lebih besar dibandingkan dengan variabel-variabel yang lain, namun masih dalam katagori rendah. Hasil penelitian ini tidak sesuai dengan penelitian yang dilakukan oleh Evi Wulandari (2013) dimana hasil penelitiannya menyebutkan bahwa terdapat hubungan yang bermakna antara intensitas pencahayaan dengan bakteri Streptococcus 
di ruangan. Perbedaan penelitian ini dengan penelitian yang dilakukan oleh Evi Wulandari adalah terletak pada lokasi, jumlah sampel, dan analisis data yang dilakukan. Lokasi dari penelitian Evi Wulandari terletak di Rumah Susun dengan jumlah sampel 32 sampel dan uji chi square, sedangkan pada penelitian ini dilakukan di rumah sakit dengan jumlah sampel 35 sampel dan uji Rank Spearman.

Hubungan Kepadatan Ruang dengan Angka Kuman Udara di Ruang Rawat Inap Kelas I, II, dan III RST Wijayakusuma Purwokerto

Hasil analisis hubungan kepadatan ruang dengan angka kuman udara menggunakan metode Rank Spearman pada aplikasi pengolah data statistik, didapatkan nilai $\mathrm{p}=0,885$. Nilai $\mathrm{p}=0,885>0,05$ yang berarti terdapat hubungan yang tidak bermakna antara kepadatan ruang dengan angka kuman udara. Nilai koefisien korelasi rho antara kepadatan ruang dengan angka kuman udara adalah sebesar 0,025. Tingkat hubungan kepadatan ruang dengan angka kuman udara berdasarkan katagorisasi koefisien korelasi rho menurut Sugiyono (2007, h.31), termasuk dalam katagori rendah.

Hasil penelitian sesuai dengan hasil penelitian yang dilakukan oleh Merlin (2012) yang menunjukkan bahwa tidak ada perbedaan konsentrasi jamur di ruangan pasien pada saat jam kunjung yang memiliki kepadatan ruang lebih banyak dibandingkan dengan bukan jam kunjung. Menurut Mandal dan Brandl dalam penelitian Merlin (2012) kemungkinan spora jamur terbawa dan menempel pada orang menjadi lebih besar dan kemudian spora terlepas ke udara ketika ruangan yang memiliki kelembapan tertentu dan kecepatan udara minimum yang dibutuhkan.

\section{Hubungan Ventilasi dengan Angka Kuman Udara di Ruang Rawat Inap Kelas I, II, dan III RST Wijayakusuma Purwokerto}

Hasil analisis hubungan antara ventilasi dengan angka kuman udara menggunakan metode Rank Spearman dengan aplikasi pengolah data statistik, maka didapatkan nilai $\mathrm{p}=0,113$. Nilai $\mathrm{p}=0,113>$ 0,05 yang berarti terdapat hubungan yang tidak bermakna antara ventilasi dengan angka kuman udara. Nilai koefisien korelasi rho antara ventilasi dengan angka kuman udara adalah sebesar 0,273. Tingkat hubungan ventilasi dengan angka kuman udara berdasarkan katagorisasi koefisien korelasi rho menurut Sugiyono (2007, h.31), termasuk dalam katagori rendah.

Hasil penelitian ini sesuai dengan hasil penelitian yang dilakukan oleh Rizka Tiara Vindrahapsari (2016), yang menunjukkan bahwa tidak ada hubungan yang signifikan antara kondisi fisik ruang dengan jumlah bakteri dalam ruang, baik yang menggunakan ventilasi sistem alami maupun yang buatan (AC).

\section{Hubungan Sarana Sirkulasi Udara dengan Angka Kuman Udara di Ruang Rawat Inap Kelas I, II, dan III RST Wijayakusuma Purwokerto}

Hasil analisis hubungan sarana sirkulasi udara dengan angka kuman udara menggunakan metode Rank Spearman aplikasi pengolah data statistik, menunjukkan bahwa nilai $\mathrm{p}=0,636$. Nilai $\mathrm{p}=0,636$ $>0,05$ berarti terdapat hubungan yang tidak bermakna antara sarana sirkulasi udara dengan angka kuman udara. Nilai koefisien korelasi rho antara sarana sirkulasi udara dengan angka kuman udara adalah sebesar 0,083. Tingkat hubungan sarana sirkulasi udara dengan angka kuman udara berdasarkan katagorisasi koefisien korelasi rho menurut Sugiyono (2007, h.31), termasuk dalam katagori sangat rendah.

Hasil penelitian ini tidak sesuai dengan penelitian yang dilakukan oleh Evi Wulandari (2013) dimana hasil penelitiannya menyebutkan bahwa terdapat hubungan yang bermakna antara sanitasi ruangan yang meliputi kebersihan dengan bakteri Streptococcus di ruangan. Perbedaan penelitian ini dengan penelitian yang dilakukan oleh Evi Wulandari adalah terletak pada lokasi, jumlah sampel, dan analisis data yang dilakukan. Lokasi dari penelitian Evi Wulandari terletak di Rumah Susun dengan jumlah sampel 32 sampel dan uji chi square, sedangkan pada penelitian ini dilakukan di rumah sakit dengan jumlah sampel 35 sampel dan uji Rank Spearman.

\section{Analisis Multivariat}

Menurut Buchori Lapau (2015), variabel yang masuk dalam kandidat multivariat adalah variabel yang memiliki nilai $\mathrm{p}<0,25$. Hasil penelitian ini menunjukkan bahwa tidak ada variabel yang memiliki nilai $\mathrm{p}<0,25$, sehingga analisis yang tidak dapat dilanjutkan ke analisis multivariat karena tidak ada variabel yang memenuhi persyaratan tersebut.

\section{Kesimpulan dan Saran Kesimpulan}

Berdasarkan hasil perhitungan, pengukuran, dan analisis data dengan uji statistik Rank Spearman, dapat disimpulkan bahwa faktor lingkungan fisik suhu, kelembaban, intensitas pencahayaan, kepadatan ruang, ventilasi, dan sarana sirkulasi udara tidak signifikan mempengaruhi keberadaan angka kuman udara di ruang rawat inap kelas I, II, dan III RST Wijayakusuma Purwokerto.

Berdasarkan hasil perhitungan, pengukuran, dan analisis data dapat disimpulkan bahwa rata-rata angka 
kuman udara di ruang Rawat Inap RST Wijayakusuma Purwokerto adalah untuk kelas I 2.833,33 CFU/m ${ }^{3}$, kelas II 2.150 CFU/m³ ${ }^{3}$, dan kelas III 29.000 CFU $/ \mathrm{m}^{3}$, sedangkan rata-rata angka kuman udara secara keseluruhan kelas I, II, dan III RST Wijayakusuma Purwokerto adalah sebesar 7871,43 $\mathrm{CFU} / \mathrm{m}^{3}$. Nilai rata-rata suhu udara di ruang Rawat Inap RST Wijayakusuma Purwokerto adalah untuk kelas I yaitu $27,33^{\circ} \mathrm{C}$, kelas II $27,22^{\circ} \mathrm{C}$, dan kelas III $27,61{ }^{\circ} \mathrm{C}$, sedangkan rata-rata suhu udara secara keseluruhan ruang rawat inap kelas I, II, dan III RST Wijayakusuma Purwokerto adalah sebesar $27,35^{\circ} \mathrm{C}$. Nilai rata-rata kelembapan udara di ruang Rawat Inap RST Wijayakusuma Purwokerto adalah untuk kelas I yaitu 54,7\%, kelas II 58,9\%, dan kelas III 56,3\%, sedangkan rata-rata kelembapan udara secara keseluruhan ruang rawat inap kelas I, II, dan III RST Wijayakusuma Purwokerto adalah sebesar 56,20\%. Rata-rata intensitas pencahayaan di ruang Rawat Inap RST Wijayakusuma Purwokerto adalah untuk kelas I yaitu 121,4 lux, kelas II 139,9 lux, dan kelas III 261,1 lux, sedangkan rata-rata intensitas pencahayaan secara keseluruhan ruang rawat inap kelas I, II, dan III RST Wijayakusuma Purwokerto adalah sebesar 154,63 Lux. Rata-rata kepadatan ruang di ruang Rawat Inap RST Wijayakusuma Purwokerto adalah untuk kelas I yaitu 13,03 $\mathrm{m}^{2} / \mathrm{TT}$, kelas II 9,31 $\mathrm{m}^{2}$ ?TT, dan kelas III 5,04 $\mathrm{m}^{2} / \mathrm{TT}$, sedangkan rata-rata kepadatan ruangan secara keseluruhan ruang rawat inap kelas I, II, dan III RST Wijayakusuma Purwokerto adalah sebesar 10,33 $\mathrm{m}^{2} / \mathrm{TT}$. Jumlah ruangan dengan ventilasi yang memenuhi syarat adalah sebanyak 34 ruang atau 97,10\%, sedangkan jumlah ruang dengan ventilasi yang tidak memenuhi syarat adalah sebanyak 1 ruang atau 2,90\%. Jumlah ruangan dengan sarana sirkulasi udara yang memenuhi syarat adalah sebanyak 29 ruang atau $82,90 \%$, sedangkan jumlah ruang dengan sirkulasi udara yang tidak memenuhi syarat adalah sebanyak 6 ruang atau $17,10 \%$.

Terdapat hubungan yang tidak signifikan antara suhu dengan angka kuman udara ( $\mathrm{p}=0,465)$ di ruang rawat inap kelas I, II, dan III RST Wijayakusuma Purwokerto. Terdapat hubungan yang tidak signifikan antara kelembapan dengan angka kuman udara $(\mathrm{p}=0,828)$ di ruang rawat inap kelas I, II, dan III RST Wijayakusuma Purwokerto. Terdapat hubungan yang tidak signifikan antara intensitas pencahayaan dengan angka kuman udara ( $\mathrm{p}=0,061$ ) di ruang rawat inap kelas I, II, dan III RST Wijayakusuma Purwokerto. Terdapat hubungan yang tidak signifikan antara kepadatan ruang dengan angka kuman udara ( $p=0,885$ ) di ruang rawat inap kelas I, II, dan III RST Wijayakusuma Purwokerto. Terdapat hubungan yang tidak signifikan antara ventilasi dengan angka kuman udara $(p=0,113)$ di ruang rawat inap kelas I, II, dan III RST Wijayakusuma Purwokerto.

Regresi suhu, kelembapan, intensitas pencahayaan, kepadatan ruang, ventilasi, dan sarana sirkulasi udara terhadap angka kuman udara tidak dapat dilakukan karena variabel-variabel dalam penelitian ini tidak memenuhi persyaratan sebagai kandidat untuk dilakukan uji multivariat.

\section{Saran}

Sebaiknya dilakukan penertiban jumlah penunggu pasien dan desinfeksi rutin setiap bulan sekali untuk menurunkan jumlah angka kuman udara. Panas matahari sebaiknya tidak dibiarkan secara langsung masuk ke ruang rawat inap pasien dan dihalangi dengan menggunakan gorden apabila tidak terdapat pohon disekitarnya. Apabila sudah menggunakan $\mathrm{AC}$, jendela ruang rawat inap sebaiknya ditutup agar AC dapat berfungsi dengan baik sebagaimana mestinya Ketika menggunakan AC, sebaiknya penghuni menutup jendela. Apabila kelembapan tetap tidak memenuhi syarat, maka dapat dipasang humidifier pada ruangan tersebut. Penanganan terhadap masalah intensitas pencahayaan, sebaiknya kebiasaan membuka jendela dan gorden dapat dimulai oleh petugas yang melakukan visitasi ke ruangan setiap hari agar dapat diikuti oleh pasien kemudian. Penataan lokasi tempat tidur pasien, sebaiknya disesuaikan dengan sumber cahaya alami agar pasien mendapatkan cahaya secara alami pada siang hari.

\section{Daftar Pustaka}

Abdullah MT, Hakim BA. 2011. Lingkungan Fisik dan Angka Kuman Udara Ruangan di Rumah Sakit Umum Haji Makassar, Sulawesi Selatan, Fakultas Kesehatan Masyarakat, Universitas Hasanuddin

Anggraini, Juaini. 2013. Jenis-jenis dan Populasi Mikroba di Laut. Fakultas Matematika dan Ilmu Pengetahuan Alam, Universitas Sriwijaya

An-Nafi', Al Fauziah. Pengaruh Kenyamanan Lingkungan Fisik Ruang Rawat Inap Kelas III terhadap Kepuasan Pasien di RSU Kustati Surakarta. 2009.

Ariyadi, T dan Dewi SS. 2009. Pengaruh Sinar Ultra Violet terhadap Pertumbuhan Bakteri Bacillus sp. Sebagai Bakteri Kontaminan, Universitas Mumammadiyah Semarang. 
Buchari, Lapau. 2015. Metodologi Penelitian Kebidanan : Panduan Penulisan Protokol dan Laporan Hasil Penelitian. Jakarta : Yayasan Pustaka Obor Indonesia

Cahyono, Tri. 2018. Panduan Penulisan Skripsi. Jurusan Kesehatan Lingkungan Purwokerto, Poltekkes kemenkes Semarang.

, Tri. 2017. Penyehatan Udara. Yogyakarta : Andi Offset

, Tri. 2006. Tabel-Tabel Statistik. Jurusan Kesehatan Lingkungan Purwokerto, Poltekkes kemenkes Semarang.

Dahlan, M. Sopiyudin. 2009. Besar Sampel dan Cara Pengambilan Sampel dalam Penelitian Kedokteran dan Kesehatan. Jakarta : Salemba Medika

, M. Sopiyudin. 2008. Statistik untuk Kedokteran dan Kesehatan. Jakarta : Salemba Medika

http://journal.unnes.ac.id/artikel_sju/ujph/3059/2827 , diakses 12-1-2018

https://id.scribd.com/document/350234373/Prosedur -Pengukuran-Parameter-Kualitas-UdaraDalam-Ruangan-Rumah-Sakit, diakses 3-12018.

http://www.academia.edu/9542738/Media_Lingkun gan_Air_Udara_Pangan_Vektor_Penyakit_B erbasis_Lingkungan, diakses 1-1-2018

http://www.bukupedia.net/2016/02/pengertian-sertaprinsip-dan-cara-kerja-termometer.html, diakses 3-1-2018.

http://www.who.int/gpsc/country_work/burden_hcai /en/, diakses 17-12-2017

Indriani, Hedy dan Santoso, Ika Puspita. Desain Pencahayaan Ruang Rawat Inap Kelas Atas Rumah Sakit Darmo dan ST. Vincentius A. Paulo Surabaya. 2009.

Keputusan Menteri Kesehatan Nomor : 129/Menkes/ SK/ II/ 2008 tentang Standar Pelayanan Minimal Rumah Sakit

Keputusan Menteri Kesehatan Nomor : 1204/ Menkes/ SK/ X/ 2004 tentang Persyaratan Kesehatan Lingkungan Rumah Sakit
Keputusan Menteri Kesehatan Republik Indonesia Nomor 1335/MENKES/SK/X/2002 tentang Standar Operasional Pengambilan Dan Pengukuran Sampel Kualitas Udara Rumah Sakit.

Lisa Jayanti, Syamsuar Manyulley, Emmi Bujawati. Kesehatan Lingkungan Udara Ruang Rawat Inap Rumah Sakit Syekh Yusuf kabupaten Gowa. 2016.

Lud Waluyo. 2007. Mikrobiologi Umum. Malang : Universitas Mumammadiyah Malang Press

Mc Kinney, RE. Microbiology For Sanitary Engineers, 1962 ; McGraw-Hill Company Inc., New York.

Merlin. Studi Kualitas Udara Mikrobiologis dengan Parameter Jamur pada Ruangan Pasien Rumah Sakit (Studi Kasus : Ruang rawat Inap Gedung A Rumah Sakit Umum Pusat Nasional Dr. Ciptomangunkusumo), Fakultas Teknik, Universitas Indonesia. 2012.

Mustika Oktarini. Angka dan Pola Kuman pada Dinding, Lantai, dan Udara di Ruang ICU RSU dr. Moewardi Surakarta. 2013.

Notoatmodjo, Soekidjo. 2002. Metodologi Penelitian Kesehatan, Jakarta : Rineka Cipta

Nugraheni, Ratna, dkk, 2012. Infeksi Nosokomial di RSUD Setjonegoro Kabupaten Wonosobo, Fakultas Kesehatan Masyarakat,Universitas Diponegoro

Oktavia, Nova. 2012. Sistematika Penulisan Karya Ilmiah. Yogyakarta : Deepublish

Pelezar MJ. 1993. Dasar-Dasar Mikrobiologi 2. Jakarta: University of Indonesia Press

Peraturan Menteri kesehatan Republik Indonesia Nomor 27 Tahun 2017 tentang Pedoman Pencegahan dan Pengendalian Infeksi di Fasilitas pelayanan Kesehatan

Santjaka, Aris. 2011. Statistik Untuk Penelitian Kesehatan. Yogyakarta : Nuha Medika.

SNI 16-7062-2004. Tentang Pengukuran Intensitas Penerangan di Tempat Kerja. 
Sugini. 2004. Pemaknaan Istilah-Istilah Kualitas Kenyamanan Thermal Ruang dalam kaitan dengan Variabel Iklim Ruang, Jurusan Arsitektur FTSP, Universitas Islam Indonesia.

Sugiyono. 2007. Metode Penelitian Pendidikan,

Pendekatan Kuantitatif, Kualitatif dan $R \& D$. Bandung: Alphabeta

Susilowati. 2008. Hubungan Intensitas Pencahayaan Ruangan, Jumlah Pasien dan Jumlah Pengunjung Pasien dengan Angka Kuman Udara di Bangsal Perawatan Kelas I, II, dan
Kelas III RS Bhakti Wira Tamtama Semarang, Universitas Mumammadiyah Semarang

Undang-Undang RI No. 44 tahun 2009 Tentang Rumah Sakit.

Vindrahapsari, Rizka Tiara. 2008. Kondisi Fisik dan Jumlah Bakteri Udara Pada Ruangan AC dan Non AC di Sekolah Dasar, Fakultas Kesehatan Masyarakat, Universitas Mumammadiyah Semarang. 